\title{
Personal Responsibility and Social Development: Implication for Global Ethics
}

\section{Samuel Asuquo Ekanem, Phd}

\author{
Centre For General Studies, Cross River University Of Rechnology Calabar - Nigeria
}

\section{Doi:10.5901/ajis.2014.v3n4p479}

\section{Abstract}

\begin{abstract}
Modernity and globalization are two contemporary concepts that tend to promote individualism within the social context. This is largely due to the competitive nature of the present age, whether as persons or nations. Also, several institutions such as the economic, political, legal and educational seem to be constructed on the basis of the individuals. This has placed a burden on the individual as to what he/she does. It is on the basis of this that personal responsibility as an obligation to oneself becomes a rational discourse within the context of social development. This is anchored on the Platonic notion that society is man's-writlarge. Based on this, it is your individual duty to ensure your good character and behaviour irrespective of how you were brought up or what kind of conditioning you have received. This becomes an imperative because if every individual takes responsibility and admit that they are the ones, not others, responsible for the choices made, then social events will reflect this thinking. For when an individual accepts the fact that he/she is morally bound and responsible for his/her action(s), then such action(s) will be taken positively to bring about individual good deeds. When all the individuals in a given society act within the bounds of responsibility and with good conscience, then the society will develop. This paper, therefore, attempts to posit that personal responsibility can promote social development where such responsibility is tainted with moral imperatives that define and constitute the social norm. This, however, will be approached from the perspectives of existentialism and essencism.
\end{abstract}

Keywords: Responsibility, Individuals, Morality, Modernity, Globalization, Existentialism and Essencism

\section{Introduction}

Globalization is not a new phenomenon but the world has never before been subject to global forces that are characterized by such extensity, intensity, velocity and impact. This can be seen as modern technology and communication effectively compress human time and space and so we regard the world as a smaller place-global village. One basic outcome of this has been the greater conduct with the "cultural other". So, we seem no longer to think of strangers and the strange as dislocated entities that are peripheral to our lives. For this to be positive experience for all there is some shortcomings to acknowledge and some hurdles to overcome. Concisely, there has been inconsistency in efforts to connect with the cultural others. This has generated social conflicts basically due to differences in tribes, ideologies, political affiliations, religions and race. The major challenge here has been the problem or inability of all persons to see humanity as one.

Again, the current neo-liberal globalization agendas do not seem to augur well for the improvement of this record of social conflicts, upheavals and turmoil. The reason for this difficulty is hinged on the promotion of individualism and lack of personal responsibility as championed by neo-liberal approaches to global conditions. This is worsened by the twin concepts of science and technology as characterized by information technology.

It may be true that the present milieu is unique in terms of the scope and nature of human activity that is present around the globe; there is a certain "kitchen table wisdom", in the words of Solomon, the wise king of Israel that "there is nothing new under the sun" (Ecclesiastes1:9). The meaning of this is that despite the technological, economic or other advances that are features of our world, it is very clear that humanistic advancement must sooner or later depend on the progress being made in the area of basic principles that relate to personal responsibility, understanding each other and acknowledging the legitimacy of other ways of knowing and being morally speaking, which may not necessarily be similar to, or consistent with our own.

This era of globalization, therefore, presents itself like other discernible epochs in which revolutions in social and scientific life have had profound impact on the ways in which we interpret ourselves, our interactions with others, our surroundings, and our place in the universe. It is indeed an opportunity for change similar to those leveraged by the material advance of the Bronze and Iron Ages and the Industrial Revolution and the intellectual vigour that characterized the Renaissance, the Reformation and Enlightenment. Such paradigmatic shifts in our perspective on material, social and spiritual matters have historically charted the course of human endeavour and presently, we stand on the cusp of an era 
in which the processes of globalization look to dramatically influence the transition of human society into the third millennium.

In anticipation of the challenges and opportunities associated with such a transformational period, the paper provides an existential and essencist treatment of two topical and related themes, global ethics, given that globalization presently is the overarching force of change in the world, and personal responsibility, which is the necessary consequence of inalienable human freedom and transcendent source and foundation for existence, social cohesion and development.

\section{Personal Responsibility and Existentialism}

Personal responsibility is an obligation to oneself; it is an individual duty for a person to ensure his/her good character and behaviour irrespective of how that individual was brought up and what kind of conditioning he/she had received. Personal responsibility includes being accountable for the degree and level of one's health, wealth, success and happiness. This reflects the right attitude because being accountable shows your maturity and wisdom. When you have the right attitude, you are less likely to create unnecessary problems in your life and in the society.

Indeed, the acceptance of personal responsibility is what distinctly separates the adult from the child. It is, therefore, the great leap forward into maturity. Responsibility is the hallmark of the fully integrated, fully functioning human being. Responsibility goes hand in hand with success, achievement, motivation, happiness and self- actualization. It is the absolute minimum requirement for the accomplishment of everything an individual could ever want in life(Tracy, 2012). To accept that one is completely responsible for oneself and the realization that no one is coming to his rescue is the beginning of peak performance. This tallies with the notion of commitment which is an existential theme or concept. Existentialism urges people to commit themselves to their freely chosen beliefs and goals, for that are the major way through which individuals could exercise their freedom, since freedom itself pre-supposes commitment.

It is through commitment that the individuals can attain or achieve freedom. Freedom, to the existentialist, forms the very structure of man, for to exist is to be free. Freedom constitutes the basic condition of human existence. Man makes himself what he wants to be. Man exists first and then creates his own essence through his free choices and actions.

The freedom of man is however tied to his responsibility. The implication of this is that every individual is free to make himself/herself what he/she wants to be or to engage him/her in any activity of his/her choice, but at the same time, the individual is responsible for whatever comes out of those freely chosen acts (Nyong and Jenkwe, 1992).

This indeed, is what the Boko Haram sect has woefully failed to realize within the context of Nigeria as a secular state. Freedom of worship and association are the fundamental rights of every citizen of Nigeria and the world. This also can be seen in the existential tenet of man and others. This is because man is not just or simply a being in-the-world, he is one that is very concerned with the objects that inhabit his environment. This makes man to realize the presence of other beings, whose existence as individual implies the existence of others. Being with others is thus discovered to be the basic element of each man's selfhood. The existence of man is thus essentially for the sake of others. However, Boko Haram in Nigeria and other fundamentalist groups globally are therefore out of tune and completely in a breach of the basic principles of existence.

The effort by Boko Haram and other fundamentalist groups in Nigeria and the world to force others to see things their way and worship what these groups believe in is a clear departure from personal responsibility. This assertion becomes clear when personal responsibility is viewed as nothing other than the freedom to create our own lives. Responsibility is equated with freedom and power. Once this is awakened among the members of the fundamentalist sects like the Boko Haram they will become liberated and empowered. Once we (they) become aware of this truth, we (they) will shed our (their) victim mentality and gain the power to transform ourselves.

The point being made here is that the social conflict prevalent in our society and the world is as a result of lack of the individual members of the society not being responsible for their deeds. It is important that we change our attitude of life by recognizing that our present situation is not the result of our genes, parent, education, job, luck, timing, health and environment. Rather it is the choices we have made and the actions we have taken that brought us to where we are today. Change your choices and actions and you will change the results. This understanding is the first step in personal transformation. The second step is the actions that follow for as noted by Dietrich Bonhoffer,"Action springs not from thought, but from readiness for responsibility" (McClure:1999). 


\section{Personal Responsibility and Ethics}

There seems to be no philosophically well-settled way of analyzing the various components of responsibility and some components are often ignored by philosophers and scholars. For this reason, this paper identifies the responsibility of individuals as four areas of enquiry. Recent analytic, moral philosophy posed two deceptively simple questions about responsibility namely:

- What is it to be responsible? and

- What is a person responsible for?

The first question anchors on moral agency and the second is about holding people accountable for past actions. This does not capture the variety of uses that we can make of the concept. Indeed, both questions might mean something distinctly different leading to the four classifications as follows:

- What is it to be Responsible? Is most often asked by philosophers as a question about the foundations of moral agency. What kind of creaturecan properly be held responsible for actions? The simple answer here is a normal human adult. To offer better explanation and justification, philosophers tendto resort to psychological and metaphysical features of normal adults, such as rationality and free- will. We can also approach the same issue with different emphasis. What features of (normal, adult) human interaction are involved in holding one another responsible?

Another question can also emerge from asking "what is it to be responsible? This can be seen when we praise some people as responsible and criticize others as irresponsible. Here, responsibility names a virtue, which is a morally valuable character trait. We may also praise an institution as responsible like "responsible government". This can be compared when we urge the Multinational Oil Companies in the Niger Delta of Nigeria to be socially responsible. This comparison and aspect of responsibility has not been given philosophical attention.

- What is a Person Responsiblefor? Is a question mostly asked by philosophers in connection with causation and accountability. This retrospective way of looking at responsibility is closely linked with praise and blame, punishment and desert. When there is something wrong, we really want to know who was at fault, but when something is good and right we tend not to ask who acted well. This falls under retrospective responsibility.

Furthermore, what a person is responsible for may imply an enquiry about a person's duty, that is, about the person's sphere of responsibility. For instance, it is the responsibility of parents to pay a child's school fees or take care of the child, government to provide security for lives and properties and the citizenry to obey the law. It emerges from here that it is a basic fact of human cooperation among people. This then puts the questions on the platform of prospective responsibility, which is responsibility that we are duty- bound to undertake. So, the two questions can provide us four distinct classifications or issues, namely, moral agency, responsibility as a virtue, retrospective responsibility and prospective responsibility.

Normal adults represent our paradigm of responsible agents. So philosophical literature has explored three wide approaches tomoral agency, and these are:

- Human beings have free will, that is, distinctive casual power or a unique metaphysical status that separates them from everything else on planet earth.

- Human beings can act on the basis of reason(s).

- Human beings have a certain set of moral or proto-moral feelings.

\section{Personal Responsibility and Social Development}

The insistence upon personal commitment gives rise to the moststrongly evaluative term in existential thinking, which is authenticity. The choices an individual makes will inevitably clash sometimes with the world outside. This is because the expectation of others, social conformity, a desire to please, unjust laws, self-doubt among others, all combine to put pressure upon the individual to betray their values. So, an authentic response to this is to stay true to yourself, not just out of stubbornness, but as a measure of your commitment to your choices (McClure, 1999).

From this is to be discovered humanism, which Sartre tried to defend in his philosophy against the accusation of radical subjectivism; as soon as there is a commitment, I am obliged to will the liberty of others at the same time as my own. I cannot make liberty my aim unless I make that of others equally my aim (2001). Once the sphere of human action is located within a community of equally free, equally responsible individuals, then a person's action(s) take on a universalized quality. We act for all humanity when we bring values into being. This notion of universalizing one's values appears Kantian but unlike Kant's categorical imperative, it is not derivable from reason but rather from the conditions of 
existing in the world.

These conditions are centered upon freedom and responsibility, twin notions that are central to existentialism and are indeed closely bound up with any ethical system. It is on the basis of this that the pillar of social development is laid. This is because development as a multi-dimensional concept can only thrive where the individuals that make up the society are first and foremost developed. Omeregbe put it thus:

The most important aspect of the development of any country (society) is indisputably the development of human personality. It is, in other words, the moral development of the citizens that constitute the country (society). To be sure, there are other aspects of development, for a living organism with many parts, each of which needs to be developed.....(24).

From this it is clear that the most vital aspect of development that a society or country needs is that of human personality. This aspect of development has to do with moral advancement or maturity, which is the mark of human development and it is the most important aspect of national or societal development. This agrees with the Platonic notion of society being "man's-writ-large". For when the individuals that make up the society are personally responsible for all their actions and do not look for the devil or who to blame, that the society can be said to have developed. The moral development of the individual members of the society is a necessary ingredient for society to make any progress. This is because a society dominated by self- interest can only produce the Hobbesian "state of nature". Any society that wishes to progress must be ready to rigidly enforce morality.

It is due to the selfish nature and lack of rapid enforcement of morality in Northern Nigerian states that has given birth to Boko Haram. Indeed, there is no moral justification for the high rate of poverty in Northern states of Nigeria. This is a region that has controlled the machinery of government at the centre for over thirty years. This control has only produced very few elitist individuals that are billionaires to the detriment of the suffering masses of the region.

Again, the resources of the region have been effectively employed to subject the masses of Northern Nigeria to servitude. Education has been denied the majority of the populace. There is also no means of liberating the minds of the people through philosophy. There is no university in Northern Nigeria that offers philosophy as a course. Indeed, there is no Department of Philosophy in any of the universities in the core northern States. This seems to leave the northern masses in the cave withno illumination in the form of sound morality, hence, the lack of social development prevalent in Northern states of Nigeria. The northern masses do not live authentically because there appears to be no freedom and responsibility which are fundamental conditions for social cohesion and development.

Indeed, the situation in Nigeria is one of a palpable lack of an essential condition for the attainment of a stable society, namely, cohesion. The consequence of this situation has been the inability of the state to perform its functions as an umpire in political, economic and social relationship. Rather than serve as a moderator, it has become a participant in many of the conflicts tearing society apart. This indicates a clear failure in the primacy of the role of the state, at times in supplementing, in most cases substituting, the convention of customs and traditions, which are grossly inadequate for regulating humans activities in complex societies, with laws that are meant to secure "the conditions for an orderly satisfaction of instincts" (Amin, 1991, 305 - 329). Due to the realization that the state cannot perform this function efficiently without enjoying the voluntary support of the people and that the best way to secure this opportunity is by going beyond coercion to ensure that individuals in the society enjoy the benefit of social cooperation, that the pursuit of public benefits has become a vital aspect of the function of the state.

It was on the premise of this that Aristotle asserts that "the state came about as a means of securing life itself, it continues is being to secure the good life" (Amin: 314).So, if you make a distinction between the regulative and beneficent functions of the state, we can assert that the stability and viability of a society would depend on its ability to achieve a balance between these two functions. The inability of Africa and some other parts of the world to make achievement of this balance a directive principle of social organization has been a source of the condition of enduring instability and lack of progress.

\section{The Need for Global Ethics}

It is an established fact that humans are social animals, but the question is, do all human beings know correctly and certainly how to live in society? A sure answer to this is really doubtful. This is anchored on the fact thatyou can remove a man fromsociety but you cannot remove society from the man. The depth to which social consciousness exist in the human race varies in everyone without any iota of doubt. A lot of people are totally ignorant of social ethics. Such people are conscious about society but it becomes difficult for them to obey the unwritten social ethics that society laid down 
right from the Biblical era in Genesis. The meaning of modesty was given right there in the Garden of Eden. The difference is simply because everyone is not made aware of social ethics in the same manner. Social ethics is a part of a person's cumulative education right from the time of birth, and that of course is dependent upon observation. Different people observe things and as a result every person has a different notion of social ethics.

Humans are creatures living in a very symbiotic society, and as such need to share, give and take, and so this becomes the first social ethics for man to internalize or learns. For when we give something to a deserving person, it does come back to us in same way or the other.

Moderation is one ethical tenet with universal application. Christian ethics anchors on this fact, and we can also see it in Socratic and Aristotelian ethics. In giving, it is important to give within limits as too many gifts can spoil a person.

Also society is built when people appreciate and praise others' talents. This applies to everyone, whether we were referring to the President or a newspaper vendor. Everyone is giving something to make the society roll, hence it is very important to give everyone their due respect. So, the lamentation of the Nigerian President as the most criticized President is indicative of the lack of this social ethics in Nigeria. Everyone has something to offer the society the world over. It is not only those in government that have all the answer to all society's problems.

Another principle that can add to our global ethics is to realize that living is fun when you live together. Here I am not referring to family, but the whole society in general, the Muslims need the Christians for several reasons and vice versa. Helping one another is a vital ingredient of togetherness. Participation is required on a national and global level also. There is the need to be aware of our politics and civics, know our rights and duties, and perform them wholeheartedly and with a sense of responsibility. Global or social ethics demands that we make a collective effort at success, like ants lifting a heavy tidbit of food. Europe needs Africa, just as Africa needs Europe. No part of the world can succeed independent of others. It is when all members of the world community work together that the world will succeed. That is how nations also succeed, and size makes no sense in this regard. Unity is strength.

Global ethics emerges from the collective experiences of people and cultures world-wide. While ethics is basically driven by individuals' morals that determine right or wrong, global ethics should focus more on what may be considered appropriate behaviour for people as a whole rather than individual's behaviour. However, without the individual there cannot be society, so there is the need to develop the individual sense of morality towards creating a global ethics.

There are certain standards of behaviour which members of society are expected to practice in order to successfully relate with one another. These should normally be based on current values or principles that dictate how people should act.

Since societal standards vary, global ethics will be influenced by such variations. However, the rights of the majority should be enforced to the extent that the rights of others are not infringed upon. There are many aspects to consider within global ethics as a whole, such as the language, race, gender, culture, religion, education, among others. The standard that should be employed in enforcing global ethics should include family values, religious beliefs, morality, integrity and so forth.

But for global ethics to work in lieu of such differences there are certain practices that must be deemed acceptable by the majority which are needed within the society. This can include sharing with others, doing good deeds, being responsible, acknowledging different viewpoints. Global ethics should also involve the acceptance of people as a whole, respect of the right of all others irrespective of individual beliefs. Humanity must be seen as one and the goal of everyone should be to actualize the essence of man as a being in the world. Nothing should be done to dehumanize humanity. The Boko Haram insurgency and other conflicts the world over are therefore a negation of these tenets of global ethics.

\section{Conclusion}

This paper has examined several themes that relate to our contemporary engagement with global ethics. From the outset, the platform of existentialism and essencism were used as a reference point to investigate personal responsibility and social development. The rationale was that an existential consideration is useful because it takes into consideration how individuals go about constructing their lives in relation to and consideration of others. There are several factors that hinder individual self- actualization especially in a global society as is currently being experienced.

There was also the historical excurses in our intellectual exploration to formulate and establish a correlation between personal responsibility and social development. It is also an existential exhortation to be authentic in our existence and relationship with others. It therefore follows that we must search within ourselves to evolve a global ethics that will enhance the individual and promote social development. For this to be attained, we must think generously, reflect deeply, react prudently and gently and be involved with daring imagination. We must evolve a new kind of respect and 
reflection in the assertion of our beliefs. It is whenthe individuals the world -over grow to take responsibility for their actions that the society will develop and a global ethics can emerge.

\section{References}

Asimor, I.The Universe: from Earth to Quasar. London: The Penguin Press, 196.

Baldwin, T.."Existentialism". In Honderich, T. (Ed), The Oxford Companion to Philosophy. Oxford: Oxford University Press, 1995,pp257261

Baumasn, Z.PostModernity and itsDiscontent.Cambridge: Polity Press,1997.

Burbahc, F. Orlando, N andKagarlitsry, BGlobalizationanditsDiscontent:The Rise of PostmodernSocialization.London: Pluto Press,1997.

Ekanem, S. A,"A Philosophy for Technological Development in Nigeria "Unpublished Doctoral Dissertation, Universityof Calabar, Nigeria,2006.

Encorte(2003) Existentialism (online)Retrieved 7thSeptember, 2012fromhttp://encerta.msn.com/encert/refpages/RefArticles.aspx?repid = anddpns $1 \#$ s.

McClure, M. (1999) Ethics, being existentialism, (online)Retrieved $7^{\text {th }}$ September, 2012.

OnlineTracy - Freedom and Responsibility. Retrieved on $7^{\text {th }}$ September, 2012.

Omeregbe, J. I.Ethics for EveryNigerian, Lagos:Shela\& Associate,1991.

Oladipo, O. Philosophy and Social Reconstruction in Africa. Ibadan: Hope Publication, 2009.

Nyong,P.D. and Jenkwe, J. Topics in Existentialism.Nigeria:Domest Educational Publishing. 
E-ISSN 2281-4612

ISSN 2281-3993
Academic Journal of Interdisciplinary Studies

MCSER Publishing, Rome-Italy
Vol 3 No 4

July 2014 